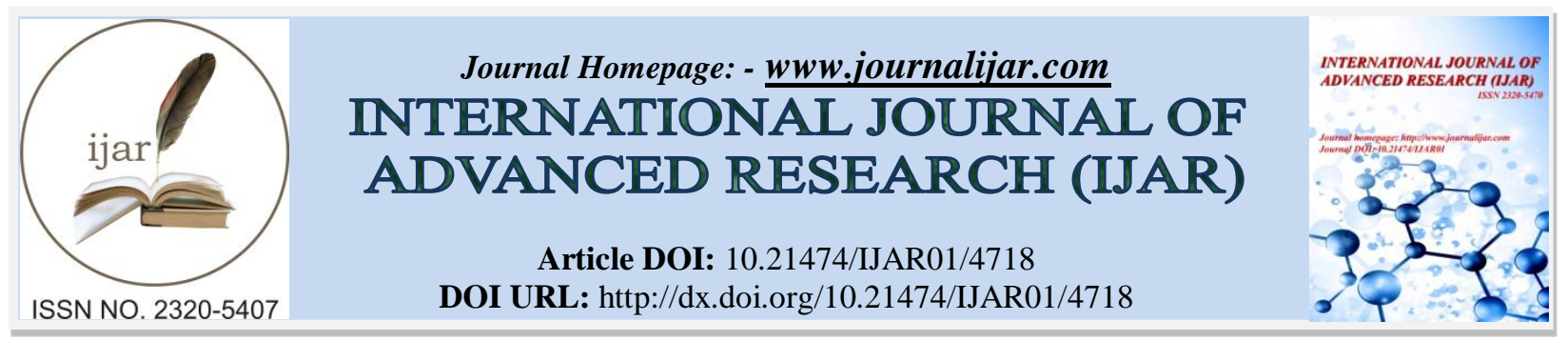

RESEARCH ARTICLE

\title{
EFFECT OF FLY ASH APPLICATION ON THE CHLOROPHYLL AND PROLINE CONTENT OF COWPEA (VIGNA SINENSIS VAR. KANCHAN) PLANT.
}

Pallavi Rai and Harbans Kaur Kehri.

Department of Botany, University of Allahabad, Allahabad.

\section{Manuscript Info}

Manuscript History

Received: 3 May 2017

Final Accepted: 5 June 2017

Published: July 2017

Key words:-

VAM fungi, Carotenoids, Chlorophyll, Cowpea, Cynodon, Proline, Rhizobium

\section{Abstract}

The present study has been undertaken to see the effect of fly ash application on the physiological parameters of Cowpea plant like Chlorophyll content and Proline content of plant. Photosynthetic pigments (Chlorophyll a, Chlorophyll b) content increased with addition of $10 \%$ fly ash, while decreased with addition of fly ash, without any amendment while Carotenoids content increased with addition of $30 \%$ fly ash, without any amended. It was also observed that Proline accumulation was more in $20 \%$ and $30 \%$ fly ash series as well as in combination with Cynodon in comparison to control. All other series showed a significant decrease in the Proline content. However the minimum Proline content was recorded in a series where soil was amended with Cynodon, $10 \%$ fly ash and inoculated with VAM fungi, PSF and nitrogen fixer (Rhizobium).

Copy Right, IJAR, 2017,. All rights reserved.

\section{Introduction:-}

In India about $70 \%$ of the electricity is generated by coal based thermal power plants which produce nearly 13 million per years of fly ash as by-product. The disposal of such enormous amount of fly ash is a major problem in areas around power stations. Although a small fraction of the fly ash is now used in land filling and also as a base material for building as well as for removal of $\mathrm{Zn}$ from the industrial effluents, its application to agricultural soils on a large scale is still very uncommon. This is because of its high alkalinity and salinity, but also because of its high content of toxic trace elements which suppress plant growth and deteriorate soil properties. On the other hand, fly ash also contains some growth-essential elements like $\mathrm{K}, \mathrm{Ca}, \mathrm{Mg}, \mathrm{Fe}, \mathrm{Zn}, \mathrm{Mo}$ which promote plant growth and physical parameter.

\section{Materials and methods:-}

Site description: For conducting the experiments in the present study, both fly ash and agriculture soil were used. Fly ash was collected from the fly ash dumping sites situated at IFFCO, Phulpur, $25^{\circ} 33^{\prime} \mathrm{N}, 82^{\circ} 6^{\prime} \mathrm{E}$ near Allahabad, Uttar Pradesh and the agriculture soil from Ganga basin region of Allahabad.(Plate 1,2) Characteristics of agriculture soil and fly ash used in the experiments are presented in Table-1.

Collection of soil samples: The rhizospheric soil samples were collected from the root region of the plants growing in the vicinity of fly ash damping site of IFFCO, Phulpur, Allahabad. Samples were brought to the laboratory in polythene bags and stored at $5^{\circ} \mathrm{c}$ until processed. 
Isolation of VAM fungi: VAMF spores were isolated by wet sieving and decanting method of (Gerdemann and Nicolson 1963). A known amount of soil was dissolved in water. After through shaking, it was left for some time for the soil particles to settle down. The clear solution was passed through sieve of 500, 350, 210, 150,90 and 60 micro meters in descending order. The VAM spores retained on various sieves were transferred on filter papers. Filter papers were examined under binocular microscope.

Identification of VAM fungi: Different VAM spores present in the soil were recovered and VAM spores were mounted in PVLG and identified to the species level using the synoptic keys of (Trappe 1982), (Schenck and Parez 1990) and INVAM species guide (http//: invam.caf.wvu.edu).

The most dominant indigenous VAM fungi were the species of Acaulospora and Glomus viz. Acaulospora denticulate, Acaulospora scrobiculata, Glomus deserticola, Glomus fasiculatum, Glomus tortosum, Glomus clarum, Glomus multicaule, Glomus intraradices, Glomus mosseae, Gigaspora sp. etc.

\section{Maintenance of Trap culture:-}

To obtain abundant and healthy spores of different VAMF species rhizospheric soils from the plants growing in the vicinity of fly ash dumping site were collected. Shoots were removed at crown and roots were chopped into small fragments. These root segments along with rhizospheric soil were mixed with autoclaved coarse sand soil mixture 1:1 ratio $(\mathrm{v} / \mathrm{v})$. These mixtures were then transferred to sterilized earthen pots and seeds of Trifolium repens (L.) were sown in each pot. Cultures were grown under greenhouse conditions for three months. After three months spore population was determined in trap cultures. Another set of trap cultures was prepared on Sorghum bicolor (L.) using the soil of first set. Mycorrhizal inoculum consisted of soil having 50 VAM spores/10 gm. soil, mycelia and infected root fragments ( $95 \%$ root length colonization). This consortium was used as inoculum for the experimental work.

\section{Isolation and Maintenance of Phosphate solubilizing microbes:-}

Soil dilution and plate count method of (Timonin 1940) was used for isolating / counting of phosphate solubilizing microbes from the rhizospheric soil of the plants growing in the vicinity of fly ash dumping site IFFCO, Phulpur, Allahabad.

All the colonies of phosphorus solubilizing microbes which appeared on the Petri plates and exhibited zone of solubilization were examined carefully, dominant species were Aspergillus niger, Cladosporium sp., Fusarium oxysporum, Penicillium sp. and sub-cultured these dominant species in Pikovskaya's broth media. They were reexamined critically, identified with the help of specific monographs and their phosphate solubilizing potentiality was estimated. Aspergillus niger highest phosphate solubilizing potentiality.

\section{Isolation and Maintenance of $\mathrm{N}_{2}$ - fixing Bacteria, Rhizobium leguminosarum:-}

Rhizobium leguminosarum was isolated from the nodules of cowpea growing in the fields near the fly ash dumping site, IFFCO, Phulpur, Allahabad on Yeast extract Mannitol Agar plates. Large gummy colonies of bacteria that emerged within four or five days were selected, isolated and subsequently transferred on fresh nutrient plates and sub cultured.

Experimental setup: The seeds of Cowpea (Vigna sinensis var. Kanchan) were procured from registered seed shop of Allahabad, which served as the unit of propagation during the experiments.

Experimental Design: An experiment was setup in pots under greenhouse condition to assess the performance of both the crops raised in agriculture soil of Allahabad amended with organic matter (Cynodon 2\% w/w), different concentration of fly ash $(10,20,30 \%)$ and inoculated with consortium of VAM fungi, PSF and Rhizobium alone as well as in combination.

The experiment had a complete randomized design in three blocks, eight treatment / block and three replicates / treatment. The treatment were as follows

\section{Block I}

- Agriculture soil (Control)

- Agriculture soil + Phosphate solubilizing fungi (Aspergillus niger) (PSF) 
- Agriculture soil + VAM

- Agriculture soil+ Rhizobium (RHZ)

- Agriculture soil + VAM+PSF

- Agriculture soil+ PSF+RHZ

- Agriculture soil+ VAM+RHZ

- Agriculture soil + PSF+ VAM+RHZ

Block II

- Agriculture soil + Organic matter (Cynodon 2\% w/w) (CN)

- Agriculture soil $+\mathrm{CN}+$ Phosphate solubilizing fungi (Aspergillus niger) (PSF)

- Agriculture soil + CN + VAM

- Agriculture soil $+\mathrm{CN}+\mathrm{RHZ}$

- Agriculture soil $+\mathrm{CN}+\mathrm{VAM}+\mathrm{PSF}$

- Agriculture soil $+\mathrm{CN}+\mathrm{PSF}+\mathrm{RHZ}$

- Agriculture soil $+\mathrm{CN}+\mathrm{VAM}+\mathrm{RHZ}$

- Agriculture soil + CN + VAM +PSF+RHZ

\section{Block III}

- Agriculture soil $+\mathrm{CN}+10 \%$ Fly ash

- Agriculture soil + Organic matter $(\mathrm{CN})+10 \%$ Fly ash + PSF

- Agriculture soil $+\mathrm{CN}+10 \%$ Fly ash + VAM

- Agriculture soil $+\mathrm{CN}+10 \%$ Fly ash + RHZ

- Agriculture soil $+\mathrm{CN}+10 \%$ Fly ash + VAM + PSF

- Agriculture soil $+\mathrm{CN}+10 \%$ Fly ash + PSF + RHZ

- Agriculture soil $+\mathrm{CN}+10 \%$ Fly ash $+\mathrm{VAM}+\mathrm{RHZ}$

- Agriculture soil $+\mathrm{CN}+10 \%$ Fly ash $+\mathrm{VAM}+\mathrm{PSF}+\mathrm{RHZ}$

\section{Block IV}

- Agriculture soil $+\mathrm{CN}+20 \%$ Fly ash

- Agriculture soil $+\mathrm{CN}+20 \%$ Fly ash + PSF

- Agriculture soil $+\mathrm{CN}+20 \%$ Fly ash + VAM

- Agriculture soil $+\mathrm{CN}+20 \%$ Fly ash + RHZ

- Agriculture soil $+\mathrm{CN}+20 \%$ Fly ash + VAM + PSF

- Agriculture soil $+\mathrm{CN}+20 \%$ Fly ash $+\mathrm{PSF}+\mathrm{RHZ}$

- Agriculture soil $+\mathrm{CN}+20 \%$ Fly ash $+\mathrm{VAM}+\mathrm{RHZ}$

- Agriculture soil $+\mathrm{CN}+20 \%$ Fly ash $+\mathrm{VAM}+\mathrm{PSF}+\mathrm{RHZ}$

\section{Block V}

- Agriculture soil $+\mathrm{CN}+30 \%$ Fly ash

- Agriculture soil $+\mathrm{CN}+30 \%$ Fly ash + PSF

- Agriculture soil $+\mathrm{CN}+30 \%$ Fly ash + VAM

- Agriculture soil $+\mathrm{CN}+30 \%$ Fly ash + RHZ

- Agriculture soil $+\mathrm{CN}+30 \%$ Fly ash + VAM + PSF

- Agriculture soil $+\mathrm{CN}+30 \%$ Fly ash $+\mathrm{PSF}+\mathrm{RHZ}$

- Agriculture soil $+\mathrm{CN}+30 \%$ Fly ash + VAM + RHZ

- Agriculture soil $+\mathrm{CN}+30$ Fly ash + VAM+ PSF + RHZ

Earthen pots were filled with $4 \mathrm{~kg}$ soil amended with $2 \%(\mathrm{w} / \mathrm{w})$ organic matter. All series were supplemented with organic matter except control series. Some sets of experiments were provided with microbial inoculations singly as well as in dual and triple combination.

The above mentioned series were set up in five blocks. In first block soil in the pots was without any amendments and maintained as control for the experiment. In the second block, soil was amended with Cynodon, in the third block soil was amended with 10\% fly ash, whereas in fourth and fifth blocks with 20 and 30\% fly ash respectively.

Crops were raised in earthen pots. Seeds were surface sterilised by $3 \%(\mathrm{v} / \mathrm{v})$ sodium hypochloride solution for 2-3 minutes and rinsed in sterilized distilled water 2-3 times and dried in shade for 10-15 minutes. In single inoculation 
series with VAM, before sowing the seeds, the mycorrhizal inoculum of VAM fungi was separately placed below the seeds by the layering method (Menge et al. 1977). The inoculum was spread as a layer at a depth of 3-5 cm in the pot and the seeds were sown just above the inoculum layer. The seeds were covered with a layer of soil to ensure an efficient host fungus association. The inoculum consisted of a mixture of infected root pieces and soil with extrametrical spores from cultures of different VAM fungi maintained on Sorghum vulgare (L.). In single inoculation series with Rhizobium, before sowing, the seeds were soaked for 4 hrs in culture suspensions of the isolate of Rhizobium (containing approximately 108 cells / $\mathrm{ml}$ ) prepared from its 8 days old cultures on YEMA liquid medium. For single inoculation series with PSF (Aspergillus niger) the seeds were soaked for four hrs in culture suspension (containing approximately 108 conidia $/ \mathrm{ml}$ ) prepared from the 10 days old culture on Pikovskayas liquid medium. For dual inoculation series involving Rhizobium and PSF, the crops were raised from seeds treated with a mixture of an equal amount of culture suspensions containing 108 cells or conidia/ml. On the other hand, in dual inoculation series involving Rhizobium or PSF and VAM fungi, the crops were raised from Rhizobium / PSF treated seeds in soil supplemented with inoculum of VAM fungi. In triple inoculation series involving Rhizobium, PSF and VAM fungi, the crops were raised from the seeds treated with Rhizobium and PSF supplemented with inoculum of VAM fungi. The seeds treated with Rhizobium or PSF in single, dual or triple inoculated series were then dried in shade and shown at 10 seeds per pot. Ten seeds per pot were sown and after finally emergence and establishment only five seedlings per pot were maintained. Five plants from each treatment series were carefully uprooted at different stages of plant growth viz; vegetative, flowering and fruiting. Samples of roots along with adhering soil were collected and processed for determining the mycorrhizal intensity in the roots and population of VAM spores.

\section{Physiological Analysis:-}

Estimation of Photosynthetic pigments Chlorophyll a, Chlorophyll b and Carotenoids:-

Concentration of photosynthetic pigments in leaves of plants was determined after extraction with acetone using the equation given by Lichtenthaler and Welburn (1983). In this method fresh leaves $(.05 \mathrm{~g}$ ) were cut into small pieces and crushed in $80 \%$ acetone for extracting photosynthetic pigments. The extract was centrifuged and the leaf pieces were again treated with $80 \%$ acetone and centrifuged. The process was repeated till the leaf pieces became colourless, final volume of the supernatant was maintained to $5 \mathrm{ml}$ with $80 \%$ acetone and the absorbance of this solution was recorded at 663, 646 and 470nm through calorimeter (Spectronics-20, Bausch \& Lomb). The amount of chlorophyll a, chlorophyll $\mathrm{b}$ and carotenoids was calculated using the equation given by Lichtenthaler and Welburn (1983).

\section{Estimation of Proline Content:-}

Proline content in the leaves of plants was estimated according to the method given by Bates et al., (1973). In this method fresh leaves $(0.5 \mathrm{~g})$ were crushed in $10 \mathrm{ml} \mathrm{3 \%}$ aqueous sulfosalicylic acid and centrifuged at $10,000 \mathrm{~g}$ for 10 min. $2 \mathrm{ml}$ tissue extract was reacted with $2 \mathrm{ml} 3 \%$ glacial acetic acid and $2 \mathrm{ml}$ acid ninhydrin solution. The reaction mixture was incubated for $1 \mathrm{hr}$ in water bath at $95^{\circ} \mathrm{c}$. after proper cooling $4 \mathrm{ml}$ toluene was added to the reaction mixture. The toluene layer was extracted after vortexing for $15 \mathrm{sec}$. with a test tube mixer and its absorbance was read at $520 \mathrm{~nm}$ through calorimeter (Spectronics-20, Bausch \& Lomb), the proline content in the sample was estimated against the standard curve.

\section{Result and Discussion:-}

In the present study photosynthetic pigments (Chlorophyll a, Chlorophyll b) increased with addition of $10 \%$ fly ash while carotenoid content decreased. In comparison to control chlorophyll 'a'and 'b' content increased up to $47.5 \%$ and $103.4 \%$ in cowpea, in a series where agriculture soil was amended with Cynodon and 10\% FA and inoculated with all the three microbial inoculants. (Table 3,4,5) (fig. 1,2) The results were supported by several authors. Srivastava et al. (1995) reported that $10 \%$ utilization of fly ash in soil showed increased photosynthetic pigments in Lactuca sativa. Photosynthetic pigments and total protein content was increased with addition of $25 \%$ fly ash (Ajaz and Tiyagi, 2003).

Singh et al. (2010) reported that $20 \%$ and $40 \%$ addition of fly ash enhanced photosynthetic pigments and total protein content in cowpea, but decrease with addition of more than $40 \%$ fly ash.

FA application to soil at a low rate has been reported to increase in the photosynthetic pigments and total protein content in different plants (Gupta et al., 2000; Khan and Khan, 1996; Sinha et al., 2013; Gupta and Sinha, 2009; Iqbal and Khan, 1995; Sharma et al., 2010; Pandey et al., 2009, 2010). 
$15 \%$ fly ash amended soil showed increase in photosynthetic pigments and total protein content is might be due to presence of high amount of K, Mg, Fe, Mn and P (Canjura et al., 1991; Rai et al., 2002; Khan and Khan, 1996; Gupta et al., 1999; Sinha et al., 2013).

Application of high amount of fly ash causes decrease in photosynthetic pigments and total protein content due to presence of metal ions or degradation of chlorophyll by free radical generated by metals (Pandey et al., 2010; Gupta et al., 1999).

The breakdown of photosynthetic pigment may be due to substitution of $\mathrm{Mg}^{2}+$ ion in chlorophyll molecules by metal ions such as $\mathrm{Cu}^{2}+, \mathrm{Zn}^{2}+, \mathrm{Cd}^{2}+, \mathrm{Pb}^{2}+, \mathrm{Ni}^{2}+$ (Kupper et al., 1998). Metals possess a potential to alter the photosynthesis rate by disturbing the structure of chloroplast leading to the changes in the fatty acid composition, inhibiting photosynthetic pigment and enzymes of Calvin cycle (Vazquez et al., 1987).

Non-enzymatic antioxidants serve as an accessory pigment for photosynthesis and protect the chlorophyll pigment under stress conditions by quenching the photodynamic reactions, replacing per oxidation and collapsing membrane in chloroplasts (Kenneth et al., 2000). The decreased level of chlorophyll may have been due to down regulation of chlorophyll biosynthesis by restricting the level of precursors or through targeting-SH groups of aminolevulinic acid dehydratase (ALAD) in the presence of metals (Prasad and Prasad, 1987; Van Assche and Clijsters, 1990).

In the present study proline accumulation was more in a series where soil was amended with $20 \%$ and $30 \%$ fly ash alone as well as in combination with Cynodon. In comparison to control decrease in proline content was recorded in cowpea and pea (Table 6) (fig. 2). Similar results were reported by several authors (Gupta et al., 2000; Khan and Khan, 1996; Sinha et al., 2013; Gupta and Sinha, 2009; Pandey et al., 2009, 2010). According to Pandey et al. (2010) accumulation of high amount of proline may be because of heavy metals present in fly ash such as $\mathrm{Fe}, \mathrm{Cu}$, $\mathrm{Ni}, \mathrm{Cr}, \mathrm{Pb}, \mathrm{Cd}$ etc. All other series showed a significant decrease in the proline content. However, the minimum proline content was recorded in a series where soil was amended with Cynodon, 10\% fly ash and inoculated with VAM, PSF and nitrogen fixer.

The results clearly indicated that the addition of organic matter and inoculation of microbes reduce the toxic effects of fly ash in leguminous crop Cowpea. 


\section{Fly ash dumping site}
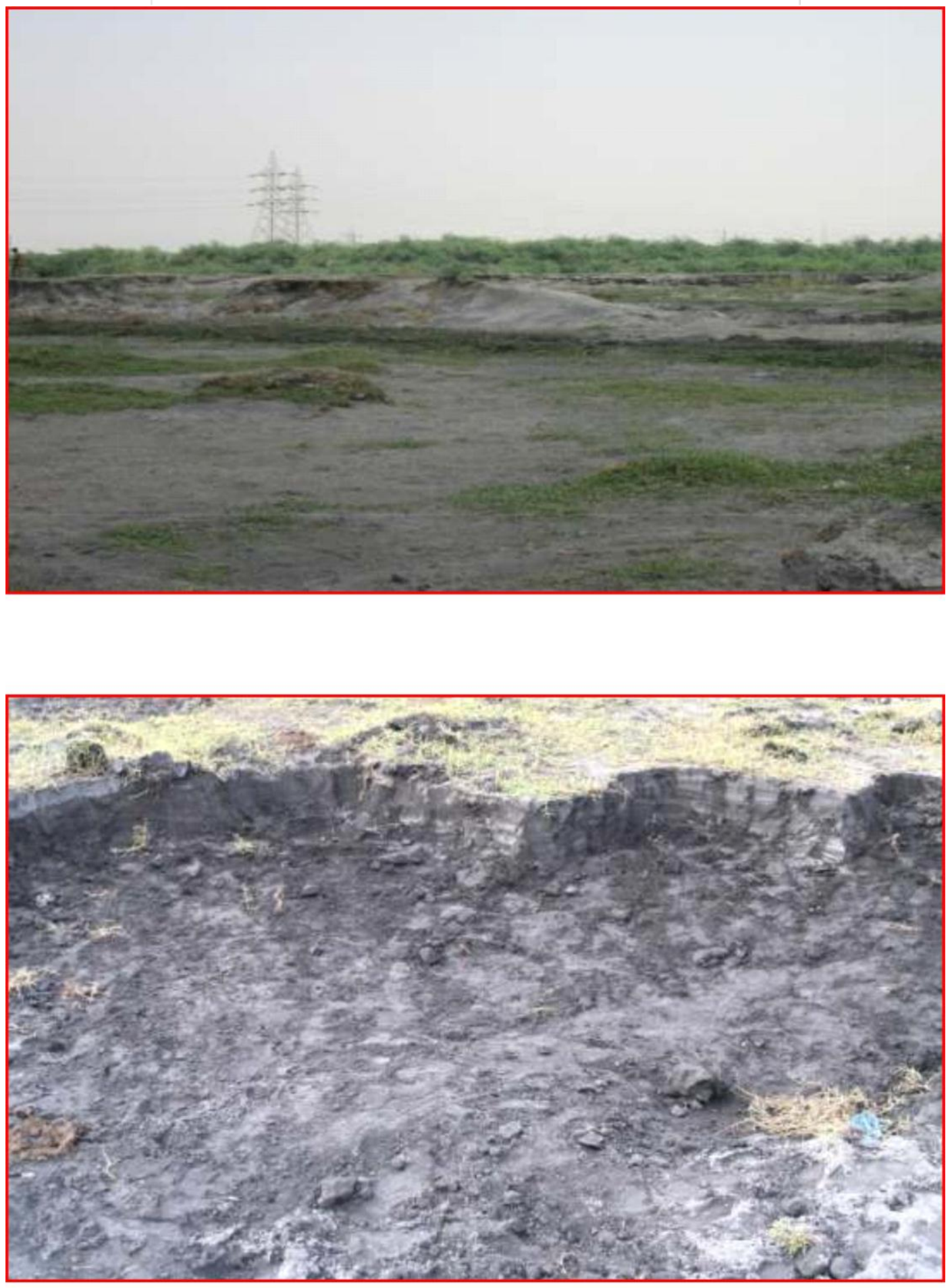

Plate 1 


\section{Ganga basin area}
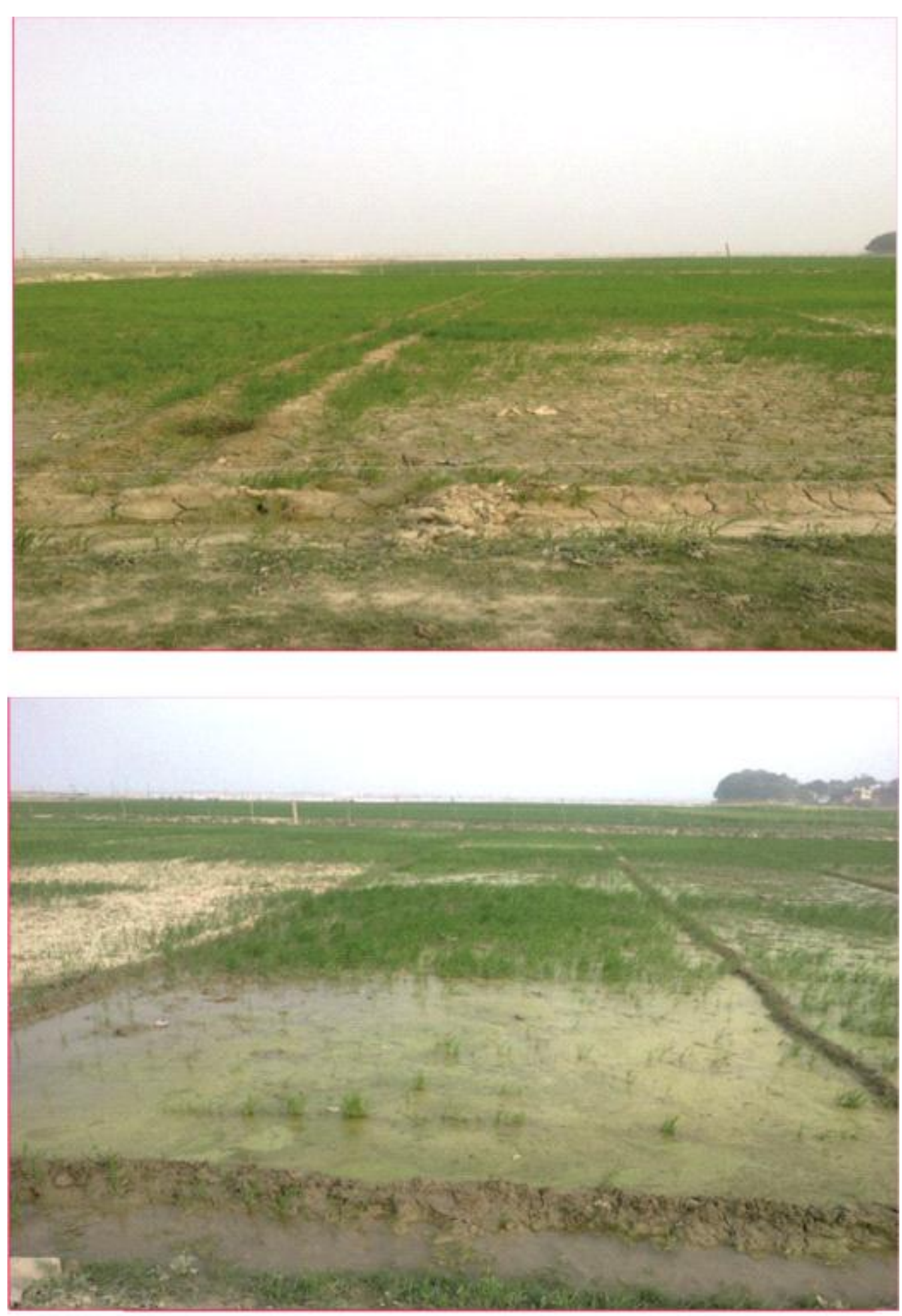

Plate 2 
Table 1:-Physico-chemical characteristics of agriculture and fly ash

\begin{tabular}{|l|l|l|}
\hline & Agriculture soil & \\
\hline Physical & & $<1.0$ \\
\hline $\mathrm{BD}\left(\mathrm{g} \mathrm{cm}^{-1}\right)$ & 1.5 & $35-40$ \\
\hline $\mathrm{W} . \mathrm{H} . \mathrm{C}(\%)$ & $22-25$ & \\
\hline \hline $\begin{array}{l}\text { Chemical } \\
\mathrm{pH}\end{array}$ & 8.1 & 7.4 \\
\hline $\mathrm{Al}_{2} \mathrm{O}_{3}(\mathrm{PPm})$ & 1.0 & 18.7 \\
\hline $\mathrm{Fe}_{2} \mathrm{O}_{3}(\mathrm{PPm})$ & 0.37 & 3.4 \\
\hline $\mathrm{CaO}(\mathrm{PPm})$ & 0.39 & 1.54 \\
\hline $\mathrm{MgO}(\mathrm{PPm})$ & 0.24 & 0.53 \\
\hline $\mathrm{Na}_{2} \mathrm{O}(\mathrm{PPm})$ & 0.008 & 0.05 \\
\hline $\mathrm{K}_{2} \mathrm{O}(\mathrm{PPm})$ & 232 & 2.5 \\
\hline $\mathrm{SO} \mathrm{S}_{3}(\mathrm{PPm})$ & 0.19 & 0.1 \\
\hline Organic carbon, \% & 1.2 & 0.42 \\
\hline Nutrient & & \\
\hline Nitrogen & 24 & 0.030 \\
\hline Phosphorus & 29 & 0.035 \\
\hline
\end{tabular}

Table 2:- The phosphate solubilizing potentiality of the isolated phosphate solubilizers

\begin{tabular}{|l|l|}
\hline P solubilizing Microbes & P solubilization (ppm) \\
\hline Aspergillus niger & $\mathbf{0 . 1 9 7}$ \\
\hline Cladosporium sp. & 0.024 \\
\hline Curvularia sp. & 0.072 \\
\hline Fusarium oxysporum & 0.124 \\
\hline Penicillium sp. 1 & 0.091 \\
\hline Penicillium sp. 2 & 0.026 \\
\hline Penicillium sp. 3 & 0.062 \\
\hline Penicillium sp. 4 & 0.026 \\
\hline
\end{tabular}

Table 3:- Chlorophyll 'b' content of cowpea plant raised in agriculture soil amended with $10 \%, 20 \%$ and $30 \%$ fly ash and Cynodon and provided with consortium of VAM fungi, PSF and $\mathrm{N}_{2}$ fixer alone as well as in combination, at fruiting stage.

\begin{tabular}{|c|c|c|c|c|c|}
\hline \multicolumn{6}{|c|}{ Chlorophyll 'b' content $(\mu \mathrm{g} / \mathrm{ml})$} \\
\hline Treatment & $\mathbf{A g S}$ & $\mathrm{CN}$ & $\begin{array}{l}10 \% \mathrm{FA} \\
+\mathrm{CN}\end{array}$ & $\begin{array}{l}20 \% \mathrm{FA} \\
+\mathrm{CN}\end{array}$ & $\begin{array}{l}\text { 30\% FA } \\
+\mathrm{CN}\end{array}$ \\
\hline Control & 0.29 & 0.38 & 0.53 & 0.51 & 0.41 \\
\hline +PSF & 0.31 & 0.38 & 0.55 & 0.53 & 0.43 \\
\hline +VAM & 0.36 & 0.39 & 0.52 & 0.50 & 0.48 \\
\hline+ RHZ & 0.29 & 0.41 & 0.61 & 0.56 & 0.51 \\
\hline +PSF+VAM & 0.31 & 0.42 & 0.58 & 0.53 & 0.46 \\
\hline +PSF+RHZ & 0.36 & 0.41 & 0.56 & 0.53 & 0.50 \\
\hline +VAM+RHZ & 0.33 & 0.43 & 0.59 & 0.52 & 0.48 \\
\hline +PSF+VAM+RHZ & 0.38 & 0.54 & 0.61 & 0.59 & 0.56 \\
\hline
\end{tabular}


Table 4:- Chlorophyll 'a' content of cowpea plant raised in agriculture soil amended with $10 \%, 20 \%$ and $30 \%$ fly ash and Cynodon and provided with consortium of VAM fungi, PSF and $\mathrm{N}_{2}$ fixer alone as well as in combination, at fruiting stage.

\begin{tabular}{|l|l|l|l|l|l|}
\hline \multicolumn{9}{|c}{ Chlorophyll 'a' content $(\boldsymbol{\mu g} / \mathbf{m l})$} \\
\hline Treatment & AgS & $\mathbf{C N}$ & $\begin{array}{l}\mathbf{1 0 \%} \mathbf{F A} \\
+\mathbf{C N}\end{array}$ & $\begin{array}{l}\mathbf{2 0 \%} \mathbf{F A} \\
+\mathbf{C N}\end{array}$ & $\begin{array}{l}\mathbf{3 0 \%} \mathbf{F A} \\
+\mathbf{C N}\end{array}$ \\
\hline Control & 0.610 & 0.690 & 0.810 & 0.780 & 0.760 \\
\hline +PSF & 0.630 & 0.730 & 0.750 & 0.720 & 0.680 \\
\hline +VAM & 0.640 & 0.730 & 0.760 & 0.730 & 0.690 \\
\hline +RHZ & 0.610 & 0.640 & 0.690 & 0.650 & 0.620 \\
\hline +PSF+VAM & 0.650 & 0.750 & 0.860 & 0.830 & 0.810 \\
\hline +PSF+RHZ & 0.670 & 0.700 & 0.720 & 0.700 & 0.670 \\
\hline +VAM+RHZ & 0.660 & 0.753 & 0.880 & 0.840 & 0.830 \\
\hline +PSF+VAM+RHZ & 0.672 & 0.757 & 0.900 & 0.870 & 0.840 \\
\hline
\end{tabular}

Table 5:- Carotenoid content of cowpea plant raised in agriculture soil amended with $10 \%, 20 \%$ and 30\% fly ash and Cynodon and provided with consortium of VAM fungi, PSF and $\mathrm{N}_{2}$ fixer alone as well as in combination, at fruiting stage.

\begin{tabular}{|l|l|l|l|l|l|}
\hline \multicolumn{7}{|c|}{ Carotenoid content $(\boldsymbol{\mu g} / \mathbf{m l})$} \\
\hline Treatment & AgS & $\mathbf{C N}$ & $\begin{array}{l}\mathbf{1 0 \%} \text { FA } \\
+\mathbf{C N}\end{array}$ & $\begin{array}{l}\mathbf{2 0 \%} \text { FA } \\
+\mathbf{C N}\end{array}$ & $\begin{array}{l}\mathbf{3 0 \%} \text { FA } \\
+\mathbf{C N}\end{array}$ \\
\hline Control & 1.230 & 1.410 & 1.273 & 1.342 & 1.888 \\
\hline+ PSF & 1.232 & 1.451 & 1.284 & 1.534 & 1.921 \\
\hline +VAM & 1.236 & 1.270 & 1.236 & 1.784 & 1.870 \\
\hline +RHZ & 1.230 & 1.410 & 1.354 & 1.865 & 2.348 \\
\hline +PSF+VAM & 1.232 & 1.451 & 1.239 & 1.789 & 2.036 \\
\hline +PSF+RHZ & 1.236 & 1.270 & 1.243 & 1.785 & 2.340 \\
\hline+ VAM+RHZ & 1.245 & 1.275 & 1.240 & 1.824 & 2.344 \\
\hline +PSF+VAM+RHZ & 1.248 & 1.279 & 1.358 & 1.884 & 2.351 \\
\hline
\end{tabular}

Table 6:- Proline content of cowpea plant raised in agriculture soil amended with $10 \%, 20 \%$ and 30\% fly ash and Cynodon and provided with consortium of VAM fungi, PSF and $\mathrm{N}_{2}$ fixer alone as well as in combination, at fruiting stage.

\begin{tabular}{|c|c|c|c|c|c|}
\hline \multicolumn{6}{|c|}{ Proline content $(\mu \mathrm{g})$} \\
\hline Treatment & AgS & $\mathbf{C N}$ & $\begin{array}{l}10 \% \text { FA } \\
+\mathrm{CN}\end{array}$ & $\begin{array}{l}20 \% \mathrm{FA} \\
+\mathrm{CN}\end{array}$ & $\begin{array}{l}30 \% \mathrm{FA} \\
+\mathrm{CN}\end{array}$ \\
\hline Control & 0.019 & 0.015 & 0.023 & 0.026 & 0.032 \\
\hline +PSF & 0.017 & 0.010 & 0.022 & 0.025 & 0.028 \\
\hline +VAM & 0.016 & 0.013 & 0.014 & 0.015 & 0.018 \\
\hline+ RHZ & 0.013 & 0.014 & 0.017 & 0.019 & 0.023 \\
\hline +PSF+VAM & 0.016 & 0.011 & 0.012 & 0.013 & 0.015 \\
\hline +PSF+RHZ & 0.009 & 0.010 & 0.017 & 0.019 & 0.021 \\
\hline +VAM+RHZ & 0.015 & 0.009 & 0.013 & 0.015 & 0.016 \\
\hline +PSF+VAM+RHZ & 0.014 & 0.008 & 0.011 & 0.013 & 0.015 \\
\hline
\end{tabular}



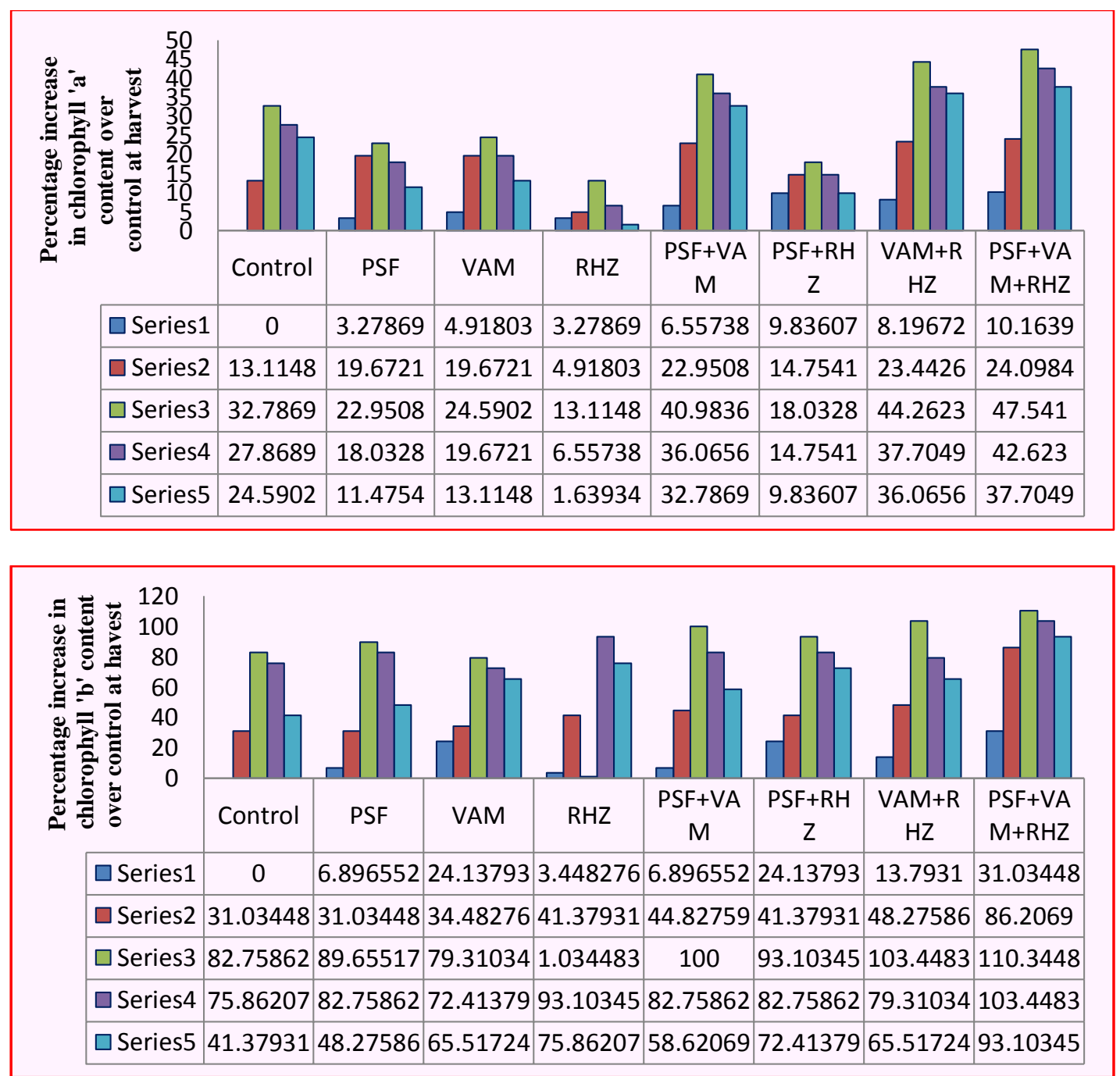

Figure 1

Series1: AgS (Agriculture soil)

Series2: AgS+CN (Cynodon)

Series3 : AgS+CN+10\%FA (fly ash)

Series4: $\mathrm{AgS}+\mathrm{CN}+20 \% \mathrm{FA}$

Series5 : $\mathrm{AgS}+\mathrm{CN}+30 \% \mathrm{FA}$ 

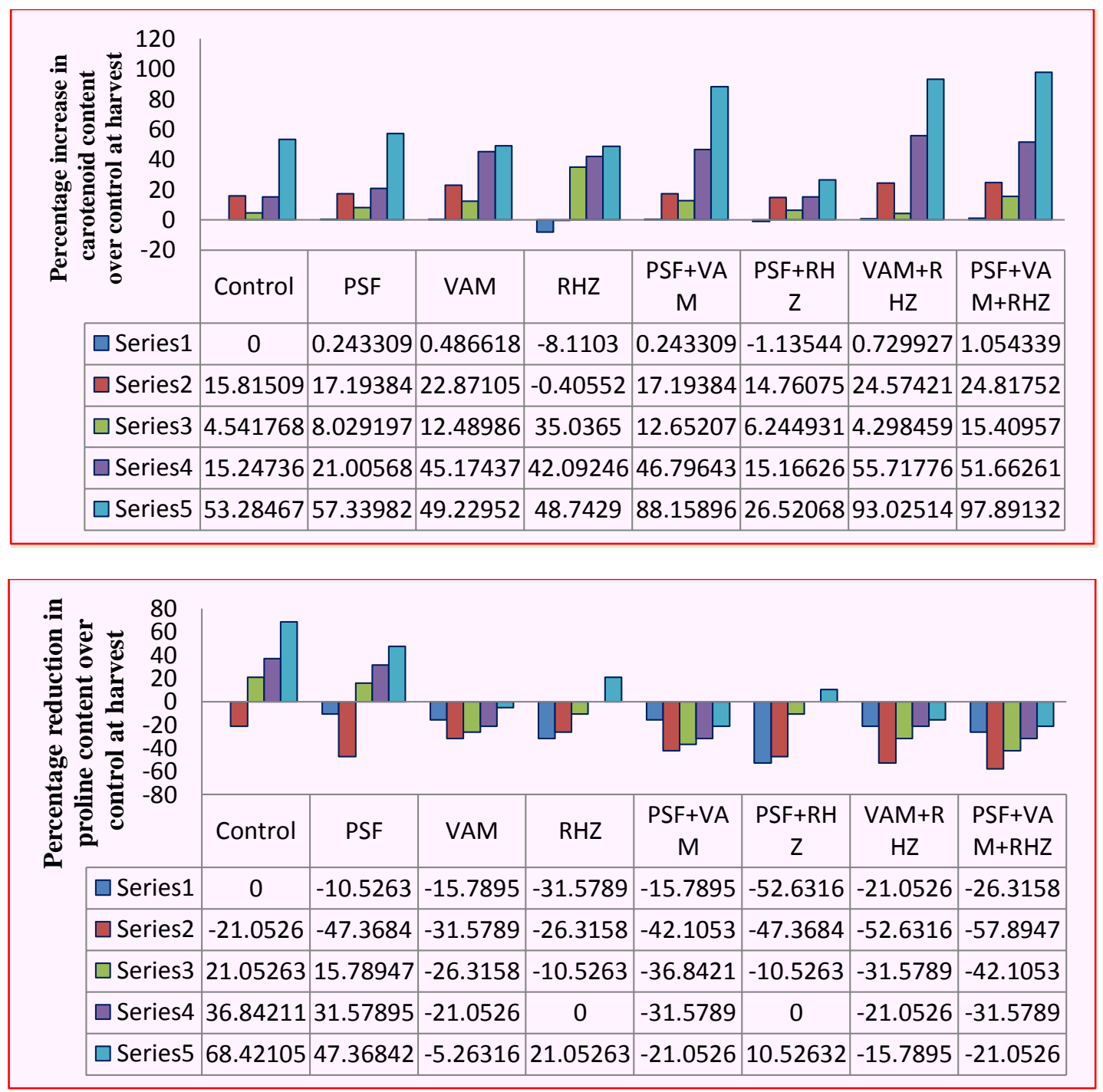

Figure 2

Series 1 : AgS (Agriculture soil)

Series2: AgS+CN (Cynodon)

Series3 : AgS+CN+10\%FA (fly ash)

Series4: AgS+CN+20\%FA

Series5 : $\mathrm{AgS}+\mathrm{CN}+30 \% \mathrm{FA}$

\section{References:-}

1. Bates, L., Waldren, R.P. and Teare, I.D. (1973). Rapid determination of free proline for water-stress studies. Plant and Soil., 39: 205-207.

2. Gupta, N.S., Sadavarte, K.T., Mahorkar, V.K., Jadhao, B.J. and Dorak, S.V. (1999). Effect of graded levels of nitrogen and bioinoculants on growth and yield of marigold (Tagetes erecta). J. Soil. Crop., 9(1): 80-83.

3. Gupta, A.K., Dwivedi, S., Sinhas., Tripathi, R.D. Rai, U.N. and Singh, S.N. (2007). Metal accumulation and growth performance of Phaseolus vulgaris grown in fly ash amended soil Bioresour. Technol., 98(17): 3404-7.

4. Kenneth, E., Pallet, K.E. and Young, J. (2000). Carotenoids, in Antioxidants in Higher Plants, R.G. Alscher and J.L. Hess, eds., CRC Press, Boca Raton, FL, pp. 60-81.

5. Khan, M.R. and Khan, M.W. (1996). The effect of fly ash on growth and yield of tomato. Environ. Pollut. 92: $105-111$. 
6. Kupper, H., Kupper, F. and Spiller, M. (1998). In situ substitution of heavy metal substituted chlorophylls in water plants. Photosynth. Res., 58: 123-133.

7. Lichtenthaler, H.K. and Wellburn, A.R. (1983). Determinations of total carotenoids and chlorophylls a and b of leaf extracts in different solvents. Bioche. Soc. Trans., 11: $591-592$.

8. Menge, J.A., Lembright, H. and Johnson, E.L.V. (1977).Utilization of mycorrhizal fungi in Citrus nurseries. Proc. Int. Soc. Citriculture., 1: 129.

9. Pandey, V.C., Abhilash, P.C. and Singh, N. (2009) b. The Indian perspective of utilizing fly ash in phytoremediation, phytomanagement and biomass production. J. Environ. Manage., 90: 2943-2958.

10. Pandey, V.C., Singh, J.S., Kumar, A., Tewary, D.D. (2010). Accumulation of heavy metals by chickpea grown in fly ash treated soil: effect on antioxidants. Clean Soil Air Water 38: 1116-1123.

11. Pikovaskaya, R.I.(1948). Mobilisation of phosphorous in connection with the vital activity of some microbial species. Microbiologiya.,17:362-370.

12. Prasad, D. D. K. and Prasad, A. R. K. (1987). 'Effect of lead and mercury on chlorophyll synthesis in mung bean seedlings', Phytochem., 26: 881.

13. Schenck, N.C. and Perez, Y. (1990). Manual for the identification of VAM fungi.University of Florida, Fainesville. J. Agric. Res., 28 : 639.

14. Timonin, M. I. (1940). The interaction of higher plants and soil microorganisms I. Microbial population of the rhizosphere of seedlings of certain cultivated plants. Canad. J. Res., 18: 307-317.

15. Trappe, J.M. and Schenck, N.C. (1982). Taxonomy of the fungi forming endomycorrhizae : A VAM fungi. In. Principle of mycorrhizal research (Ed. N.C. Schenck) Amer. Phytopatho.Soc. St. PauL pp. 1-9.

16. Van Assche, F. and Clijsters, H. (1990). 'Effect of metals on enzyme activity in plants', Pl. Cell Environ., 13: 195.

17. Vazquez, M.D., Poschenriedr, C. and Barcello, J. (1987). Chromium VI induced structural and ultrastructural changes in bush bean plants (Phaseolus vulgaris L.). Ann. Bot., 59: 427-438. 